\title{
The Development of Questioning Skills through Hikmah (Wisdom) Pedagogy
}

\author{
Hafizhah Zulkifli1 ${ }^{*}$, Rosnani Hashim² \\ ${ }^{1}$ Faculty of Education, Universiti Kebangsaan Malaysia, Bangi, Malaysia \\ ${ }^{2}$ Kuliyyah of Education, International Islamic University Malaysia, Gombak, Malaysia \\ Email: `hafizhah_zulkifli@ukm.edu.my, rosnani@iium.edu.my
}

How to cite this paper: Zulkifli, H., \& Hashim, R. (2019). The Development of Questioning Skills through Hikmah (Wisdom) Pedagogy. Creative Education, 10, 2593-2605.

https://doi.org/10.4236/ce.2019.1012187

Received: October 16, 2019

Accepted: November 24, 2019

Published: November 27, 2019

Copyright (c) 2019 by author(s) and Scientific Research Publishing Inc. This work is licensed under the Creative Commons Attribution International License (CC BY 4.0).

http://creativecommons.org/licenses/by/4.0/ (c) (i) Open Access

\begin{abstract}
The ability to ask and answer questions is central to learning. Questioning is one of the thinking processes that can stimulate critical thinking among students. However, it can be seen that students have yet to master the questioning skill and are still in the lower order thinking (LOTs) questions. Therefore, this research aims to improve students questioning after the implementation of Hikmah Pedagogy. The research will reveal student's improvement in critical thinking through the evidence from student's questions. The subjects of the study consist of 27 students who are chosen to participate in the implementation of Hikmah Pedagogy. The results show an improvement where the students were able to produce questions from lower order thinking questions (LOTs) to higher order thinking questions (HOTs) according to Hierarchy of Bloom's Taxonomy. This research recommends teacher to apply Hikmah Pedagogy in order to enhance critical thinking among students.
\end{abstract}

\section{Keywords}

Hikmah Pedagogy, Lower Order Thinking Questions (Lots), Higher Order Thinking Questions (Hots), Questions

\section{Introduction}

Education is a very important aspect of life. Education consists of knowledge, skills and values transmitted in order to produce a good human being. According to Al-Attas (1993), knowledge (ilm) can be defined as the arrival of the meaning of an object of knowledge in the soul or the arrival of the soul at the meaning of an object of knowledge. Through the presence of knowledge, man can be guided to do the right things and acknowledge God as his creator. He will also be able to act and behave in the most righteous manner in which his 
behaviors are not only done specifically for his conduct of this world but also of the hereafter (Hashim, 2017a). Thus, education acts as a medium, which brings a person to arrive at wisdom leading to justice and fulfilment of his faith (Hashim, 2017a). Education should solely focus and emphasize on teaching students on how to think for themselves in order to provide them the opportunity to arrive at the state of wisdom (Taylor, 2012). However, school today has become an instrument rather than an institution that educates which has created a distorted culture that believes that education revolves around the obsession with assessment by examination (Taylor, 2012; Hashim, 2017b). Teachers tend to turn to spoon-feeding which unconsciously kills the sense of curiosity and the excitement of discovery, which leads to the loss of interest in learning due to the goal of achieving excellent results (Taylor, 2012; Hashim, 2017a). Dewey (1897) and Lipman (2003) claim that education as the above stated scenario results in the failure of cultivating inquiry, critical thinking, reasonableness, and judgment. According to Dewey (1897), education is not merely the transmission of knowledge but it should also promote thinking.

Thinking is a process of seeking and knowing the relationship between object, idea and concept in order to find meaning. Good thinking requires higher order thinking (HOTs) as asserted by Bloom, which involves analysis, synthesis, and evaluation. Higher order thinking can be developed through questions in classroom as it is suggested that thinking process skills which are structurally embedded in the thinking operation of critical thinking, creative thinking, and problem solving can be obtained through questioning (Schirripa and Steiner, 2000: p. 210 as cited in Chin \& Osborne, 2008).

Questioning is a path to critical thinking and it is an intellectual process that facilitated through questions which lead students to integrate ideas into a harmonious concept or idea and eventually an individual as a whole. Thus, teacher should remember that critical thinking is all about the students' journey through ideas to reach the students' destination, not the teacher's (Christenbury \& Kelly, 1988). Questions will provide an opportunity for students to find out their own thoughts as teachers are opened to hear to what the students say and allowing students to explore topics and argue points of view where students function as experts where teacher creates a space for students to interact among themselves and provide immediate response to the learning (Christenbury \& Kelly, 1988).

Some of the effective questioning practices include 1) effective teacher phrasing questions clearly, 2) effective teacher asking questions which are primarily academic, 3) effective teachers asking high frequencies of low SES students in elementary setting, 4) effective teachers asking high cognitive level questions, 5) effective teachers allowing 3 - 5 seconds of wait time after asking a question before requesting a response, particularly when higher order cognitive level questions are asked, 6) effective teacher encouraging students to respond in some way to each question asked, 7) effective teacher balancing responses from volunteering and non-volunteering students, 8) effective teachers permitting students call-outs in low SES classes while suppressing call outs in high SES classes, 
9) effective teachers encouraging a high percentage of correct responses from students and assisting with incorrect responses, 10) effective teachers probing students responses for clarification, supporting for a point of view or to stimulate thinking, 11) effective teachers acknowledging correct respond SES from students but are specific and discriminating in their use of praise (Croom \& Stair, 2005).

According to Schmidt (1993), questions that come from students are crucial in activating their existing knowledge, focusing their learning efforts and helping them elaborate on their knowledge. Lipman (2003) suggested teachers have to create a culture, which could expand their student's thinking through questioning their own thoughts. One programme that provides the opportunity for children to questioning is Philosophy for Children (P4C). Philosophy for Children is a programme that assists students on how to think independently. The main objective of this programme is to develop thinking and reasoning skills among students using philosophical discussion where students are involved in the formation of a community of inquiry in the classroom (Lipman, Sharp, \& Oscayan, 1980; Juperi, 2011).

Children begin to think philosophically when they begin to ask the question "why". Thus, the importance of questioning skills will be present among children. Children will progress beyond the boundaries of their own experience through their own questioning and this will happen to help in building relationships that expand these boundaries (Splitter \& Sharp, 1995).

In Malaysia, P4C has been renamed as Hikmah (wisdom) Pedagogy and was pioneered by Rosnani Hashim. Hikmah pedagogy of Philosophical Inquiry encourages students to be engaged in critical questioning and creative reflection where both discussion and questioning are built on the nature of philosophy (Hashim, 2017a). There were several researches in Malaysia on students questioning such as a study by Juperi (2010), which focused on the philosophical inquiry in Islamic Education and its effects on the development of questioning skills among secondary school students revealed that, students were found to display significant improvements in their ability to create and pose questions, demonstrating Bloom's Higher Order Thinking Skills of analyzing, synthesizing and evaluating. She used the qualitative method of observation throughout the eight sessions of philosophical inquiry.

In addition, another study was also conducted by Hamzah (2015) who also focused on the study in Islamic Education, which confirmed that the use of philosophical inquiry approach really assisted students to ask philosophical questions. The study was carried out for six sessions and the question quadrant on a checklist was used. It was found that the students began to think when they wanted to pose questions by referring to the text.

Alias (2017) on the other hand conducted a qualitative design to explore whether the method of philosophical inquiry using stories from Quran is able to enhance the cognitive behaviour of the Community of Inquiry (COI) in P4C and identify the barriers of critical thinking among students. The findings showed that 
there were some improvements in the cognitive behaviours of COI where the children became motivated to participate in the discussion. The students also claimed that the class was enjoyable and different from their regular class, they gained confidence and was able to express their thoughts freely and meaningfully.

In reality, the students are lacking of opportunity to think due to teachers' practice of asking lower order thinking questions (Wahap, 2003; Salleh, 2005; Baki, 2001). Teachers have difficulties in creating HOTs questions and students' have problem understanding HOTs questions (Kassim \& Zakaria, 2015). Mahmood \& Lim (2011) asserted that teacher's usually practice questioning skills which cover more in lower order thinking questions rather than the higher order thinking skills questions, where the questions usually focus on individual and community and less questions on country. In addition, during formative evaluation, Abdul Mutalib \& Ahmad, (2012) stated that teacher uses lower order thinking skills such as knowledge and comprehension question during induction, then in development stage, the teacher also asks lower order of thinking questions and some HOTs questions in conclusion but insufficient throughout the teaching and learning in classroom.

Muthy (2013), added that the teacher's question is not balanced during teaching and learning as the lower order thinking questions posed by the teacher consist about $21.9 \%$ of knowledge, $63.9 \%$ comprehension, $5.8 \%$ analysis, $7.1 \%$ synthesis and $1.3 \%$ evaluation questions.

A following research showed in the findings that there were four types of pattern of verbal questioning flow which was the emerging during the teaching process in order to understand certain concepts in Electrochemistry as stated by Ikhsan $(2016 ; 2012)$. These patterns were the single questioning flow, the separated questioning flow, the continuous questioning flow and the spiral questioning flow. This study also found that teacher's verbal questions are more focused on the pattern of separated questioning flow rather than the other three patterns. This condition implies that the verbal questioning practice in the teaching process is still at the low level of cognitive. This strongly shows that teachers need to improve the use of questioning skill continuously in order to enhance the development of scientific concepts during the teaching and learning process.

From the above situation, it was shown that teacher's lower order thinking skills resulted in the students having a lack of opportunity to ponder on their thoughts and lack questions in the classroom. Though there are a few past researches on teacher's questioning skills, there is not much research on questioning skills among students; hence this research is in hope to fill the gap. There is only one or two researches on questioning skills using P4C program especially in Islamic religious Education and none of the researches focused on questioning skills in Moral education. Therefore this study addresses these shortcomings. The aim of this study is to explore student's improvement in critical thinking through the evidence from student's questions during Hikmah (wisdom) Pedagogy. 


\section{Methodology}

In this study, the researcher used qualitative research design especially observation. The purpose of the observation was to evaluate students questioning skills. To assist the researcher in every observation, the researcher used video and camera recording in order to record the observation. According to Merriam and Tisdell (2016), "It is much more likely that a researcher will jot down notes during observation and furtherly wait to record in detail what has been observed". The main purpose of the observation is to identify the students' questions on every conducted session.

The samples consisted of thirteen male students and fourteen female students. There were nineteen Indian students and eight Chinese students in a Moral Education class in a public secondary school in Gombak. The sample was chosen due to the diversity of non-Muslim students in the school, the ability to attain cooperation from the school administrator and the conducive environment for teaching and learning offered by the school.

Next, the analysis of the kinds of questions that were asked and reflected on their critical thinking was analyzed using Bloom's Taxonomy that consists of six levels: knowledge, comprehension, application, analysis, synthesis and evaluation. Taxonomy is hierarchical which means that learning at the higher levels is determined by the ability to attain previous knowledge and skills obtained at the lower levels (see Figure 1).

\section{Results}

\subsection{Session 1}

The topic for session 1 was "Volunteers". In this session, the material used was a picture of a child who had been saved by volunteers. Firstly, the teacher showed the picture to the students and asked the students to create several questions from the picture. The students were puzzled and did not know what to do. So, the teacher demonstrated with a question and then asked the students to create

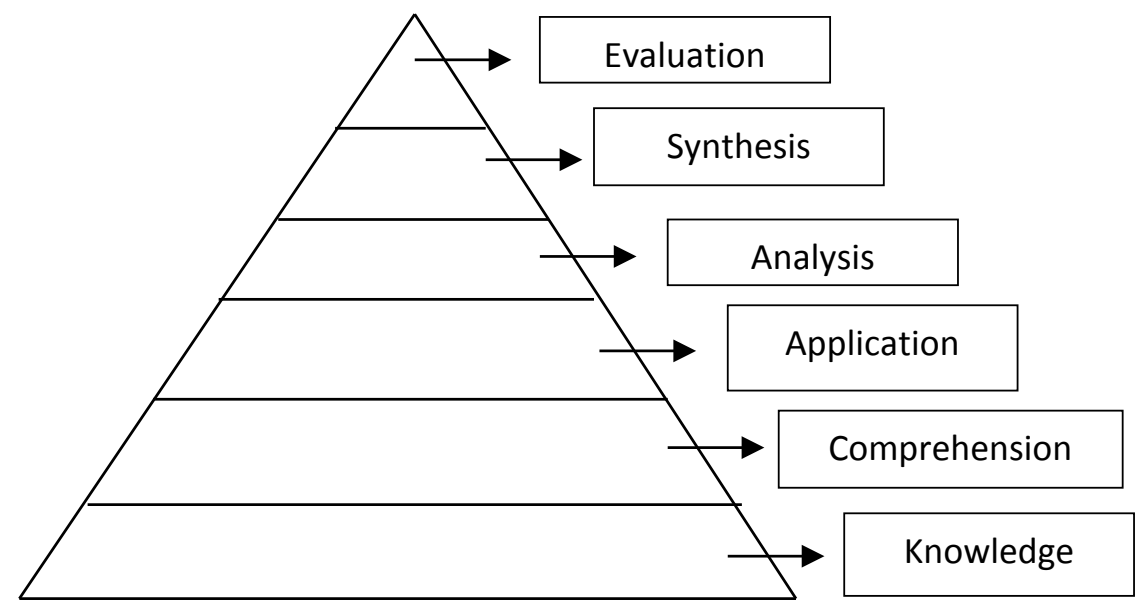

Figure 1. Bloom's taxonomy of learning (Yen \& Halili, 2015). 
their own questions. The teacher asked questions such as, "What do you understand from the meaning of 'voluntary'?" And "What is the meaning of 'a volunteer'?"

From all the questions posed by the students, it was found that three of the questions fell under the category of Lower-Order thinking (LOT) skills (see Table 1); for example, knowledge (three questions). Two questions were found to be of Higher-Order thinking skills (HOTs); one question required analysis and another evaluation. In this session, all the questions were generated by the students.

\subsection{Session 2}

In the second session, the topic covered was "Respecting Women's Rights is Everyone's Responsibility". The material used was a video showing discrimination of women that can be reached at https://www.youtube.com/watch?v=qY404OZOnEQ. It was observed that the students were focused on watching the video and claimed that the video was a real life situation. There was one LOTs question and three HOTs questions (see Table 2). Starting from this session, the teacher limited the number of questions posed to only four to five questions due to time constraint.

\subsection{Session 3}

In this session, the topic was "Vandalism", and the material was taken from YouTube. The teacher showed a video report by ASTRO AWANI, entitled "Third-class mentality threatens MRT's sophistication," which can be reached at https://www.youtube.com/watch?v=Wggz3dqm92A. After watching the video, the students raised five questions. Three of the questions generated were LOTs and two were HOTs (see Table 3).

Table 1. Bloom's taxonomy analysis in session one.

\begin{tabular}{|c|c|c|}
\hline & Questions & Bloom's Taxonomy \\
\hline \multirow{3}{*}{ LOTs Questions } & 1) Who helps the victims? & Knowledge \\
\hline & 2) What is the victim's gender? & Knowledge \\
\hline & 3) Where does the victim get help? & Knowledge \\
\hline \multirow[t]{2}{*}{ HOTs Questions } & $\begin{array}{l}\text { 4) Can you determine the importance of becoming a } \\
\text { volunteer? }\end{array}$ & Analysis \\
\hline & 5) Do you agree with the act of helping others? Explain why. & Evaluation \\
\hline
\end{tabular}

Table 2. Bloom's taxonomy analysis in session two.

\begin{tabular}{llc}
\hline \multicolumn{1}{c}{ Questions } & Bloom's Taxonomy \\
\hline LOTs Questions & 1) Who has been fired by the employer? & Knowledge \\
& 1) Why does the employer fire the female worker? & Analysis \\
HOTs Questions & 2) Why should we respect women's right? & Analysis \\
& 3) In your opinion, is it reasonable that men and \\
women are given equal rights and treatment? & Evaluation \\
\hline
\end{tabular}


Table 3. Bloom's taxonomy analysis in session three.

\begin{tabular}{llc}
\hline & \multicolumn{1}{c}{ Questions } & Bloom's Taxonomy \\
\hline \multirow{2}{*}{ LOTs Questions } & 1) What are the things being destroyed? & Knowledge \\
& 2) Who is destroying public amenities? & Knowledge \\
3) What is the meaning of vandalism? & Comprehension \\
HOTs Questions & 1) Why do they want to destroy public amenities? & Analysis \\
& 2) What are the effects of vandalism? & Synthesis \\
\hline
\end{tabular}

\subsection{Session 4}

In this session the students were given a short text on moral dilemma entitled "Callen Ong Steals the Medicine". The students were asked to pose several questions from the dilemma. The questions generated by students are shown in Table 4.

\subsection{Session 5}

Session 5 was carried out at the library. The topic was "The Wise Consumer". The stimulus material was taken from a YouTube video showing the methods sellers use to cheat buyers, (Shopkeepers Amazing Knight Machine Tricks to cheat customers) at https://www.youtube.com/watch?v=ABVGrIZ0ysM. Similar to the previous session, the students were asked by the teacher to get ready with the questions right after watching the video. There were five questions raised altogether, two of which were LOTs and three were HOTs (see Table 5).

\subsection{Session 6}

As for the sixth session, the topic was "Road Safety is Our Responsibility" and the material used was a picture of a road accident. It was observed that the students were ready with their questions. With regards to the students' questions, four were recorded on the whiteboard, of which all of them are classified under HOT questions (see Table 6).

\subsection{Session 7}

In this session, the topic was "Protecting Coral Reefs". The material used was a short story on coral reef thefts. The students read the story one by one and posed questions afterwards. A total of four HOTs questions were posed during the session (see Table 7).

\subsection{Session 8}

In session 8, the PI approach was held for approximately 45 minutes. It was because the school had an English programme and the students needed to go for their recess early. The students started the session by reading a short text of moral dilemma and then generated several questions (see Table 8).

\subsection{Session 9}

As for the ninth session, the topic was "Children's Rights" and the material used 
Table 4. Bloom's taxonomy analysis in session four.

\begin{tabular}{llc}
\hline \multicolumn{1}{c}{ Questions } & Bloom's Taxonomy \\
\hline LOTs Questions & $\begin{array}{l}\text { 1) Who is Melissa? } \\
\text { 2) If your mother was sick, would you be willing to } \\
\text { steal the medicine? }\end{array}$ & $\begin{array}{l}\text { Knowledge } \\
\text { Application }\end{array}$ \\
1) Why can't Calllen afford to buy the medicine? & Analysis \\
HOTs Questions & $\begin{array}{l}\text { 2) Do you agree with Callen's act of stealing the } \\
\text { medicine? Why? }\end{array}$ & Evaluation \\
\hline
\end{tabular}

Table 5. Bloom's taxonomy analysis in session five.

\begin{tabular}{llc}
\hline \multicolumn{1}{c}{ Questions } & Bloom's Taxonomy \\
\hline \multirow{2}{*}{ LOTs Questions } & 1) What products have been used to cheat consumers? & Knowledge \\
& $\begin{array}{l}\text { 2) How does a seller cheat consumers when weighing } \\
\text { goods? }\end{array}$ & Comprehension \\
& 1) Is the act of cheating consumers good? & Evaluation \\
HOTs Questions & 2) What will happen if all seller cheat consumers? & Synthesis \\
& 3) Why is it important to know about consumer right? & Analysis \\
\hline
\end{tabular}

Table 6. Bloom's taxonomy analysis in session six.

\begin{tabular}{lc}
\hline \multicolumn{1}{c}{ Questions } & Bloom's Taxonomy \\
\hline $\begin{array}{l}\text { 1) How can we reduce the number of road accidents? } \\
\text { 2) What are the effects of road accidents on victims and } \\
\text { their families? }\end{array}$ & $\begin{array}{l}\text { Synthesis } \\
\text { Synthesis }\end{array}$ \\
$\begin{array}{l}\text { 3) What is the relationship between road accidents and } \\
\text { the act of not adhering to the speed limits? }\end{array}$ & Analysis \\
4) Why do road accidents occur? & Analysis \\
\hline
\end{tabular}

Table 7. Bloom's taxonomy analysis in session seven.

\begin{tabular}{|c|c|c|}
\hline & Questions & Bloom's Taxonomy \\
\hline \multirow{4}{*}{ HOTs Questions } & 1) What is the importance of protecting coral reefs? & Analysis \\
\hline & $\begin{array}{l}\text { 2) Predict what will happen when Siew takes the piece of } \\
\text { coral. }\end{array}$ & Synthesis \\
\hline & 3) How do we protect coral reefs from being destroyed? & Synthesis \\
\hline & $\begin{array}{l}\text { 4) Do you agree with Siew's action of sneaking home with } \\
\text { the piece of coral? }\end{array}$ & Evaluation \\
\hline
\end{tabular}

Table 8. Bloom's taxonomy analysis in session eight.

\begin{tabular}{lll}
\hline \multicolumn{1}{c}{ Questions } & Bloom's Taxonomy \\
\hline LOTs Questions & $\begin{array}{l}\text { 1) Who informed Melissa that she has not a long time to } \\
\text { live? }\end{array}$ & Knowledge \\
HOTs Questions & $\begin{array}{l}\text { 1) Can we take medicine to end our life quickly? } \\
\text { 2) Pave the medicine according to Melissa's desire? }\end{array}$ & $\begin{array}{l}\text { Evaluation } \\
\text { ganthesis- }\end{array}$ \\
\hline
\end{tabular}

was a video. The teacher played a video entitled, "Our Children in Cotabato Street" and asked students to pose questions based on the video. A similar procedure was carried out as the previous session and five questions were recorded 
for this session. Like session six, the analysis of the questions in this session shows that the students had started to ask more and more HOT questions. In this case, five HOT questions were posed by the students (see Table 9).

\subsection{Session 10}

The tenth session started by a reading of a short text on moral dilemma. After that, the students posed several questions from the text. The students wrote the questions on the white board (see Table 10). All the questions were generated by the students.

\subsection{Session 11}

This was the final session for this study. The topic chosen was "Respecting Parents" and the material was a video of a mother ( $U m i)$ looking for peace in Baitul Mawaddah (senior care house by Selangor Zakat). The students managed to raise four HOT questions (see Table 11).

\section{Summary of Trends on Students' Question Level}

According to the chart below (Figure 2), the students started posing HOTs questions from session 6 to session 11. Then, from session 1 to session 11, there was an upward trend in Higher Order Thinking Skills (HOTs) questions and the number reached a peak at session 6 and session 7. After that, the HOTs questions dropped moderately at session 8 and session 10 but managed to reach a peak again at session 9 and session 11. In contrast, there was a downwards trend in Lower Order Thinking Skills (LOTs) from session 1 to session 11. This means that the students improved from posing LOTs questions to HOTs questions consistently.

Table 9. Bloom's taxonomy analysis in session nine.

\begin{tabular}{lc}
\hline \multicolumn{1}{c}{ Questions } & Bloom's Taxonomy \\
\hline 1) What are the rights of the children in the video? & Evaluation \\
2) Why is educating children important? & Analysis \\
3) Why are protecting children important? & Analysis \\
HOTs Questions & 4) What are the steps that can be taken to protect \\
children's rights? & Synthesis \\
5) Predict what would happen if children's rights are & Synthesis
\end{tabular}

Table 10. Bloom's taxonomy analysis in session ten.

\begin{tabular}{lc}
\hline \multicolumn{1}{c}{ Questions } & Bloom's Taxonomy \\
\hline 1) Why is telling the truth so important? & \multicolumn{1}{c}{ Analysis } \\
2) Do you agree if the tailor reported Callen Ong to the & Evaluation \\
HOTs Questions & $\begin{array}{l}\text { police? Why? } \\
\text { 3) Should we forget the mistakes that people have done } \\
\text { 20 years ago? }\end{array}$
\end{tabular}


Table 11. Bloom's taxonomy analysis in session eleven.

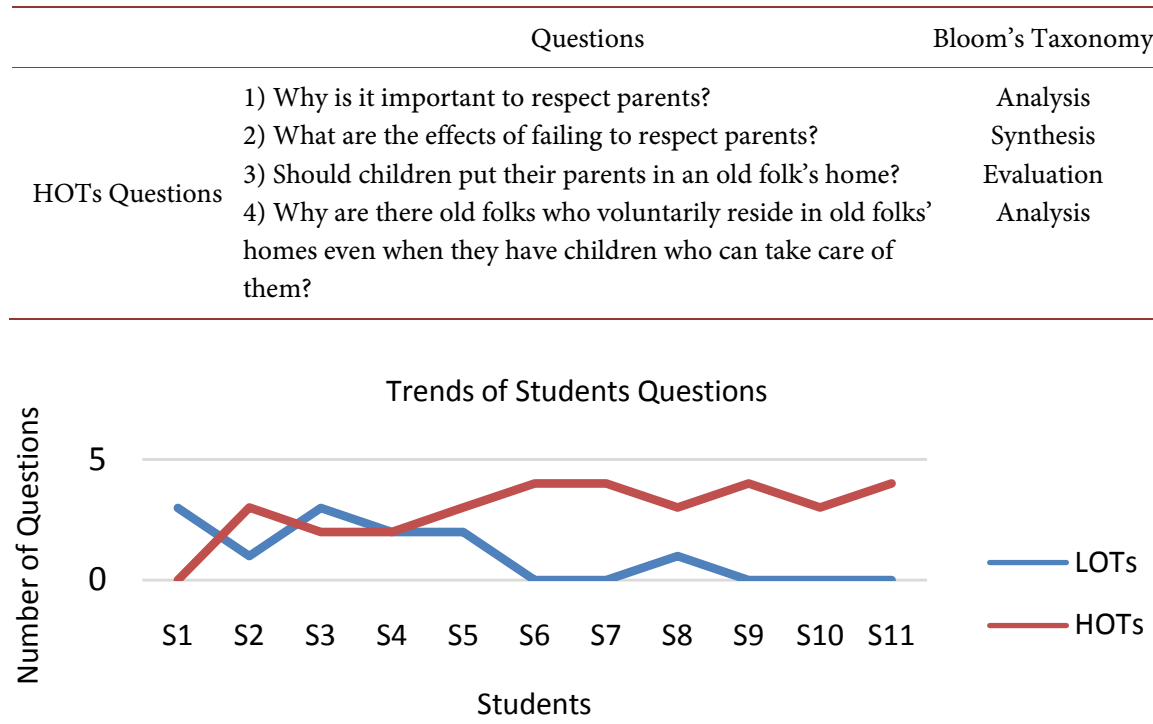

Figure 2. Trends on students' questions level.

\section{Discussion}

The findings from the questions students posed in class showed that they have increased their ability in questioning skills. At the beginning of the research, the analysis shows that the questions raised by students mostly were factual in nature and the type that Bloom categorized as knowledge, understanding, and application, or lower order thinking skills. By the end of the study, students' questioning patterns showed that more questions were of the analysis, evaluation, and synthesis, or higher order thinking skills.

The explanation for this increase in students' score of critical thinking is the influence of questioning concept from Lower Order Thinking questions (LOTs) to Higher Order Thinking questions (HOTs), a philosophical discussion concept that requires students to reason, justify, imagine, seek solution, and give alternatives and exercises that focus on concept. The stimulus materials in the forms of thinking stories, thinking pictures, or thinking videos helped students to think critically.

Similarly, the finding concurred with the findings by Juperi (2011), where students asked higher order thinking questions than lower order thinking questions. This finding also matched with Alias's (2017) research that used Bloom's Taxonomy analysis from students' questions. The study indicates that the students were able to give information and explore the relationship, then categorize, compare, contrast and organize it. However, they have not extended to the level of evaluating and creating yet, where they could give critiques and judgement.

In this study, students were motivated to ask questions and as the study progressed, the quality of the questions increased tremendously. This can be explained from the use of the stimulus materials such as texts, thinking stories, 
thinking pictures, etc., in the lesson. These play an essential part in triggering the inquisitive minds of the students. The dilemma faced by the characters in the stories are those which are common to the students' life as they could relate and share the same experience. For instance, in the topic of wasting water, they can relate the dilemma with their life and start questioning the effect of wasting water.

When introducing Philosophy for Children in a Greek kindergarten, Gasparatou and Kampeza (2015) found that PI promoted critical thinking skills in early childhood education. It is evident that children started to think critically at this stage as they gave reasons for their opinions, made judgements, evaluated their ideas, and even drew inferences.

Furthermore, the findings verify Haynes and Muris (2011) and Topping \& Trickey's (2014) claims that philosophical inquiry method promotes students to ask higher order thinking questions. This finding coincides with Wan Yusoff (2018) where it was asserted that low achievers were also capable in asking higher order thinking questions, clarifying meaning, giving examples, making conclusion and inductive reasoning, distinguishing and classifying ideas. As a study progresses, students questioning pattern will show that higher order thinking questions will be asked as compared to lower order thinking (Juperi, 2011).

\section{Conclusion}

The infusion of Hikmah Pedagogy into teaching and learning in Moral Education makes more meaningful experience to Moral Education students. It is due that, this study had shown students' display improvements in higher order thinking questions.

\section{Acknowledgements}

The authors express their appreciation to Ministry of Education Malaysia (MOE), State Education Department, district Education officers, school principle, teachers and students for their involvement in this research. This research was supported by the Faculty of Education, Universiti Kebangsaan Malaysia code PP-FPEND-2019.

\section{Conflicts of Interest}

The authors declare no conflicts of interest regarding the publication of this paper.

\section{References}

Abdul Mutalib, S., \& Ahmad, J. (2012). Kepelbagaian Aras Soalan Lisan Dalam Pentaksiran Formatif Bagi Subjek Geografi. Jurnal Teknologi, 59, 103-108.

Al-Attas, S. M. N. (1993). Islam and Secularism. Kuala Lumpur: Institute of Islamic Thought and Civilization. 
Alias, H. (2017). Teaching Thinking through Stories from the Qur'an Using Philosophy for Children Method. Unpublished Master's Thesis, Kuala Lumpur: International Islamic University Malaysia.

Baki, R. (2001). Interaksi Lisan Dalam Pengajaran Penulisan Bahasa Melayu. Doctoral Thesis, Bangi: Faculty of Education, National University of Malaysia.

Chin, C., \& Osborne, J. (2008). Students' Questions: A Potential Resource for Teaching and Learning Science. Studies in Science Education, 44, 1-39. https://doi.org/10.1080/03057260701828101

Christenbury, L., \& Kelly, P. P. (1988). Questioning a Path to Critical Thinking.

Croom, B., \& Stair, K. (2005). Effective Questioning for Effective Learning. The Agricultural Education Magazine, 78, 12-14.

Dewey, J. (1897). My Pedagogic Creed. School Journal, 54, 77-80.

Gasparatou, R., \& Ergazaki, M. (2015). Students' Views about Their Participation in a Philosophy Program. Creative Education, 6, 726-737. https://doi.org/10.4236/ce.2015.68075

Hamzah, L. M. (2015). Using Philosophical Inquiry Methods to Enhance Students' Inquiry Skills in Teaching Aqidah among Form 2 Students. Unpublished Master's Project Paper, Kuala Lumpur: International Islamic University Malaysia.

Hashim, R. (2017a). Revitalization of Philosophy and Philosophical Inquiry in Muslim Education, the Way Forward. Six Professional Lexture Series, Kuala Lumpur: International Islamic University Malaysia.

Hashim, R. (2017b). P4C in the Context of Muslim Education. In S. Naji, \& R. Hashim (Eds.), History, Theory and Practice of Philosophy for Children: International Perspectives (pp. 170-179). London: Routledge. https://doi.org/10.4324/9781315208732-20

Haynes, J., \& Murris, K. (2011). The Provocation of an Epistemological Shift in Teacher Education through Philosophy with Children. Journal of Philosophy of Education, 45, 285-302. https://doi.org/10.1111/j.1467-9752.2011.00799.x

Ikhsan, Z. (2016). Soalan Lisan Dalam Proses Pengajaran. Ukmbangi.

Ikhsan, Z., \& Sarojini Daniel, E. G. (2012). Corak Aliran Penyoalan Lisan Guru dalam Proses Pengajaranbagi Tajuk Elektrokimia. Jurnalpendidikan Malaysia, 37, 57-67.

Juperi, A. J. (2011). Philosophical Inquiry in Islamic Education and Its Effect in the Development of Questioning Skills among Secondary School Students. Unpublished Master's Thesis, Kuala Lumpur: International Islamic University Malaysia.

Kassim, N., \& Zakaria, E. (2015). Integrasi Kemahiran Berfikir Aras Tinggi Dalam Pengajaran Dan Pembelajaran Matematik: Analisis Keperluan Guru. In Prosiding Seminar Education Graduate Regional Conference (pp. 60-67). Medan: Unimed Press.

Lipman, M. (2003). Thinking in Education (2nd ed.). New York: Cambridge University Press. https://doi.org/10.1017/CBO9780511840272

Lipman, M., Sharp, A. M., \& Oscanyan, F. S. (1980). Philosophy in the Classroom (2nd ed.). Philadelphia, PA: Temple University Press.

Mahmood, Z., \& Lim, N. R. (2011). Kepelbagaian Kaidah Penyoalan Lisan Dalam Pengajaran Guru BM: Kaedah Pemerhatian. Jurnal Pendidikan Bahasa Melayu, 51-65.

Merriam, S. B., \& Tisdell, E. J. (2016). Qualitative Research: A Guide to Design and Implementation (4th ed.). San Francisco, CA: Jossey Bass.

Muthy, G. (2013). Aras Penyoalan Dan Pemikiran Dalam Proses Pembelajaran Bahasa Melayu Murid Sekolah Rendah. Tesis Sarjana Linguistik, Kuala Lumpur: Universiti Malaya. 
Salleh, S. (2005). Interaksi Lisan Dalam Pengajaran Dan Pembelajaran Komponen Kesusasteraan Melayu (Komsas) Dalam Mata Pelajaran Bahasa Melayu. Doctoral Thesis, Kuala Lumpur: Faculty of Education, National University of Malaysia.

Schmidt, H. G. (1993). Foundation of Problem-Based Learning: Rationale and Description. Medical Education, 17, 11-16. https://doi.org/10.1111/j.1365-2923.1983.tb01086.x

Splitter, L., \& Sharp, A. M. (1995). Teaching for Better Thinking: The Classroom Community of Enquiry. Melbourne: Acer.

Taylor, J. L. (2012). Think Again: A Philosophical Approach to Teaching. London: Continuum International Publishing Group.

Topping, K. J., \& Trickey, S. (2014). The Role of Dialogue in Philosophy for Children. International Journal of Educational Research, 63, 69-78.

https://doi.org/10.1016/j.ijer.2013.01.002

Wahap, W. (2003). Penggunaan Penyoalan Lisan Dalam Kalangan Guru Sejarah Di Sekitar Bandar Sibu. Kertasprojeksarjana Pendidikan. Fakulti Pendidikan, Bangi: Universiti Kebangsaan Malaysia.

Wan Yusoff, W. M. (2018). The Impact of Philosophical Inquiry Method on Classroom Engagement and Reasoning Skills of Low Achievers. Journal of Curriculum and Teaching, 7, 135-146. https://doi.org/10.5430/jct.v7n1p135

Yen, T. S., \& Halili, S. H. (2015). Effective Teaching of Higher Order Thinking (HOT) in Education. The Online Journal of Distance Education and e-Learning, 3, 41-47.

https://tojdel.net/journals/tojdel/articles/v03i02/v03i02-04.pdf 